Article

\title{
Synthesis, Crystal Structure and Anti-Fatigue Effects of Some Benzamide Derivatives
}

\author{
Xianglong Wu ${ }^{1, \dagger * *}$, Wutu Fan ${ }^{1, \dagger}$, Yalei Pan ${ }^{1}$, Yuankun Zhai ${ }^{1}$, Yinbo Niu ${ }^{1}$, Chenrui Li $^{1}$ and \\ Qibing Mei ${ }^{1,2, *}$
}

1 Key Laboratory for Space Bioscience and Biotechnology, School of Life Sciences, Northwestern Polytechnical University, Xi'an 710072, China

2 Department of Pharmacology, School of Pharmacy, Fourth Military Medical University, Xi'an 710032, China

$\dagger$ These authors contributed equally in this work.

* Authors to whom correspondence should be addressed; E-Mails: wuxianglong@nwpu.edu.cn (X.W.); gahpyudx@163.com (Q.M.); Tel./Fax: +86-29-8477-4552 (Q.M.).

Received: 4 December 2013; in revised form: 10 January 2014 / Accepted: 10 January 2014 /

Published: 16 January 2014

\begin{abstract}
A series of benzamide derivatives such as 1-(1,3-benzodioxol-5-ylcarbonyl) piperidine (1-BCP) were synthesized by the reaction of substituted benzoic acids with piperidine, morpholine or pyrrolidine using a novel method. The crystals of these benzamide derivatives were obtained by recrystallization. Structures of target and intermediate compounds were determined via FT-IR, ${ }^{1} \mathrm{H}-\mathrm{NMR}$ and elemental analysis and X-ray crystallography of select examples. The crystal structures of these compounds have potential applications to identify the binding site for allosteric modulators of the $\alpha$-amino-3-hydroxy-5-methylisoxazole-4-propionic acid (AMPA) receptor. The anti-fatigue effects of the benzamide derivatives in weight-loaded forced swimming mice were investigated in a swimming endurance capacity test used as an indicator of fatigue. The swimming times to exhaustion were longer in the $\mathbf{b 3}, \mathbf{d} \mathbf{3}$, and $\mathbf{e} \mathbf{3}$ groups than in the caffeine group ( $p<0.05$ ). In conclusion, $\mathbf{b 3}, \mathbf{d} \mathbf{3}$ and $\mathbf{e} 3$ enhanced the forced swimming capacity of mice. The mechanism of the anti-fatigue effects will be studied in the future.
\end{abstract}

Keywords: benzamide derivatives; 1-BCP; X-ray diffraction; synthesis; anti-fatigue effects 


\section{Introduction}

Ionotropic glutamate receptors are the major excitatory amino acid neurotransmitter receptors in the vertebrate central nervous system (CNS). There are three functionally distinct receptor subclasses: $\alpha$-amino-3-hydroxy-5-methyl-4-isoxazolepropionic acid (AMPA), kainate and N-methyl-D-aspartate (NMDA) [1]. AMPA receptors mediate most of the fast excitatory amino acid transmission in the CNS $[2,3]$. Attention has focused on drugs that modulate AMPA receptors because of their potential to enhance memory and treat certain pathologies [4]. Positive allosteric modulators of AMPA may have an advantage over direct-acting agonists or compounds that promote glutamate release, in that such drugs could increase glutamatergic tone, without the obvious liability for direct receptor-mediated excitotoxicity [5].

Ampakines are small benzamide compounds that are positive allosteric modulators of AMPA receptors in the mammalian brain. Ampakines were initially derived from the nootropic drug aniracetam which was discovered by Ito et al. [6]. Several ampakine compounds (see Figure 1), including 1-BCP, CX516, CX554, CX546 and CX614 can facilitate synaptic plasticity and improve learning and memory in both animals and humans [7].

Figure 1. Chemical structures of ampakines.

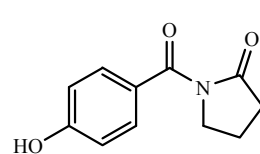

Aniracetam

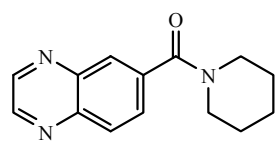

CX516

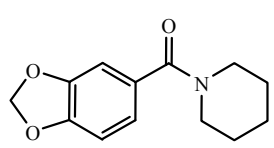

1-BCP

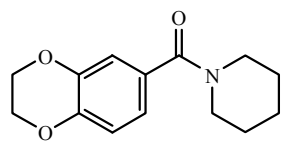

CX546
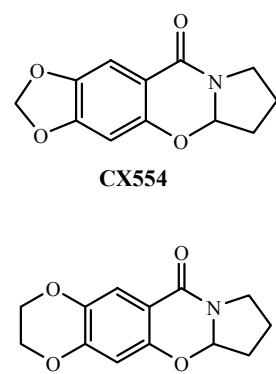

CX614

These compounds contain as common element a benzamide core, usually in the form of a benzoylpiperidine or a benzoylpyrrolidine. They play a potential therapeutic role in the treatment of neurodegenerative disorders, cognitive impairment, depression, Alzheimer's disease and schizophrenia [8]. They have also been shown to be effective in animal models to treat various neuronal disorders [9] and to enhance viability of neurons [10], probably by promoting expression of growth factors [11].

In this paper, we synthesized several benzamide derivatives which contain a benzamide core and studied their unexpected anti-fatigue activity in the laboratory. To this end we first investigated their anti-fatigue activity by weight-loaded forced swimming tests using a mouse model.

Numerous methods have been developed toward the synthesis of benzamide derivatives. Formation of the amide bond has been one of the most widely studied reactions in organic chemistry [12]. It has been taken for granted that amide bond formation is easily realized by reacting an activated carboxylic acid with an amine.

Generally, most amides are prepared by the condensation of carboxylic acids and amines in the presence of dehydrating reagents, such as $\mathrm{B}(\mathrm{OMe})_{3}$, TsCl/Py, $\mathrm{TiCl}_{4}, \mathrm{Ph}_{2} \mathrm{POCl}, \mathrm{Ph}_{3} \mathrm{P} / \mathrm{PySSPy}, N, N^{\prime}-$ dicyclohexylcarbodiimide (DCC), cyanuric chloride, 2-halo- $N$-methylpyridinium, and (benzotriazol-1yl) oxy-tris(dimethylamino)phosphonium hexafluorophosphate (BOP), or the carbonylation of aryl 
halides with amines in the presence of $\mathrm{Pd}(\mathrm{OAc})_{2}$, and $\mathrm{CO}$, etc. [13]. These methods all have some advantages and disadvantages.

As a result, we report in this paper a convenient approach for the synthesis of amides. Substituted benzoic acids were first treated with N-hydroxysuccinimidyl trifluoroacetate (NHS-TFA). Then, the resulting intermediates were treated with piperidine, morpholine or pyrrolidine to give the target compounds. Unexpectedly, crystals of the intermediate or target compounds were also obtained. All compounds were analyzed via FT-IR, ${ }^{1} \mathrm{H}-\mathrm{NMR}$ and elemental analysis. The anti-fatigue activity of the benzamide derivatives in weight-loaded forced swimming mice was then investigated. Detailed results and discussion are elaborated in the following sections.

\section{Results and Discussion}

\subsection{Synthesis and Structural Confirmation}

Benzamide derivatives are typically prepared by chlorination of benzoic acids followed by amidation of the resulting acid chlorides with an amine compound. Although the purified product can be obtained by flash column chrmatography, difficulties can't be avoided if using this method [14]. 1-BCP was also prepared by the reaction of piperonaldehyde with an equimolar amount of piperidine at $100{ }^{\circ} \mathrm{C}$ in the presence of $\mathrm{RuH}_{2}\left(\mathrm{PPh}_{3}\right)_{4}$ catalyst [15]. A specific catalyst was used in this method. Beller and co-workers used CataCxium $\mathrm{A}$ at $80-130{ }^{\circ} \mathrm{C}$ and 2 bar $\mathrm{CO}$ pressure as the ligand for primary amide synthesis from various substituted aryl bromides and heteroaryl bromides [16]. Recently, palladium-based homogeneous catalysts were also reported for substrates such as benzyl chlorides and aryl chlorides [17].

In this paper, piperonylic acid was treated with $N$-hydroxysuccinimidyl trifluoroacetate (NHS-TFA) at room temperature (Scheme 1). Then, the intermediate was reacted with piperidine to give the target compound 1-BCP, which could be easily purified by recrystallization from ethanol. The approach provided an efficient and environmentally friendly pathway to synthetic benzamide compounds [18] in good to excellent yields. A total of ten benzamide derivatives were synthesized. The compounds were characterized by elemental analysis, FT-IR, ${ }^{1} \mathrm{H}-\mathrm{NMR}$ and X-ray crystallography. The information provided should be useful in the area of medical or pharmaceutical applications.

Scheme 1. Synthesis of benzamide derivatives.

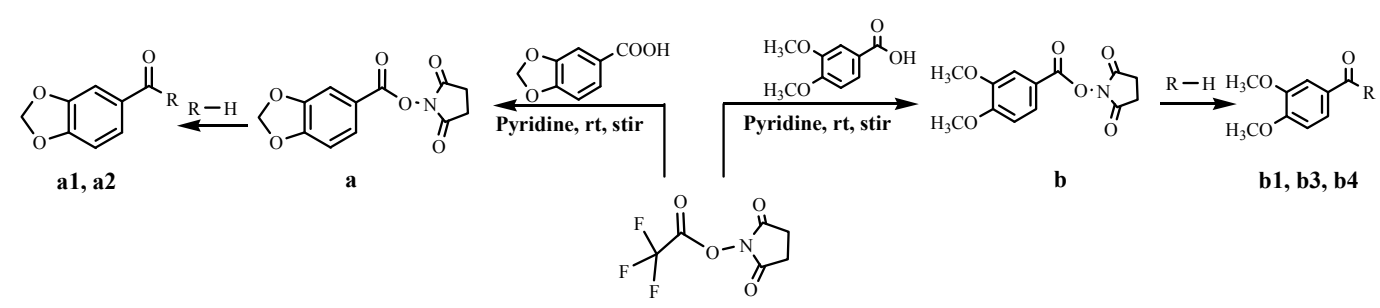

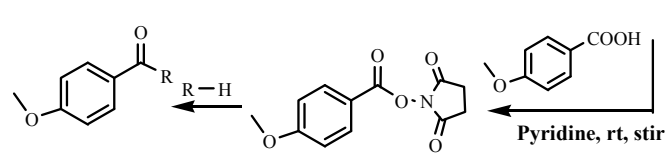

d1, d2, d3

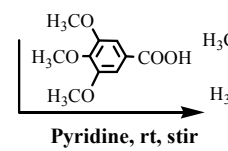

Pyridine, rt, stir 


\subsection{Crystal Structures}

Single crystals of compounds $\mathbf{a}, \mathbf{a} 2$ and $\mathbf{e} 2$ were obtained by recrystallization and their structures were further confirmed by X-ray diffraction determination. The data of compounds $\mathbf{a}, \mathbf{a} 2$ and $\mathbf{e} 2$ are deposited as CCDC Nos. 815292, 960811 and 960813, respectively. The perspectives and packing views are shown in Figures 2 and 3, respectively. The crystal data, details concerning data collection and structure refinement are listed in Table 1.

Figure 2. ORTEP drawings of molecules a, a2 and $\mathbf{e} 2$ with $30 \%$ probability displacement ellipsoids.

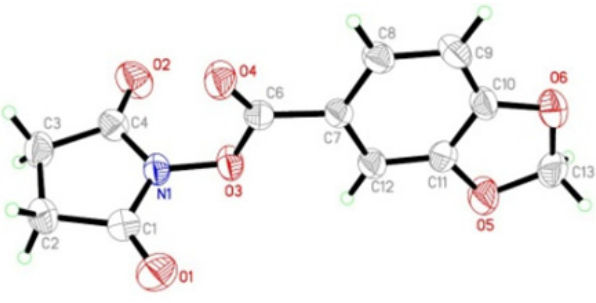

Compound a

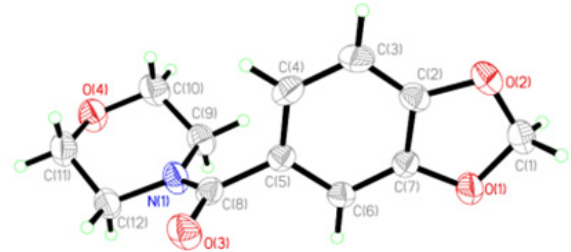

Compound a2

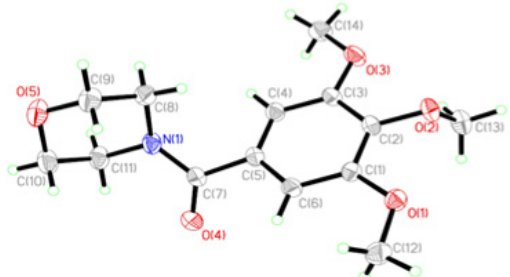

Compound e2

Figure 3. View of the molecular packing in $\mathbf{a}, \mathbf{a} 2$ and $\mathbf{e 2}$.

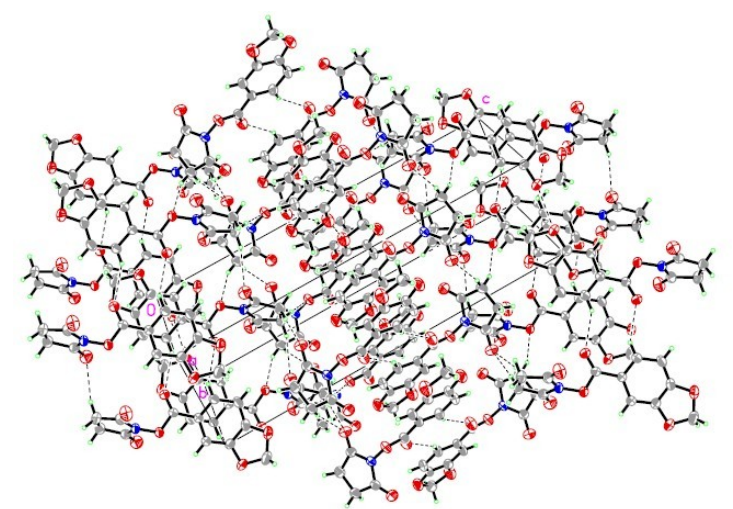

Compound a

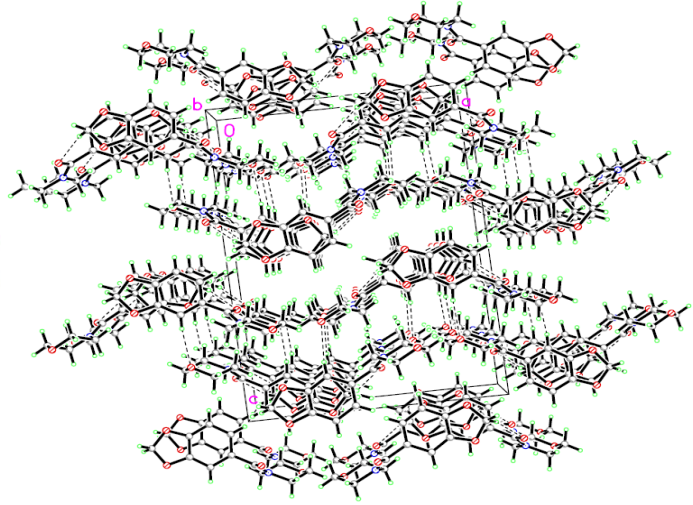

Compound a2

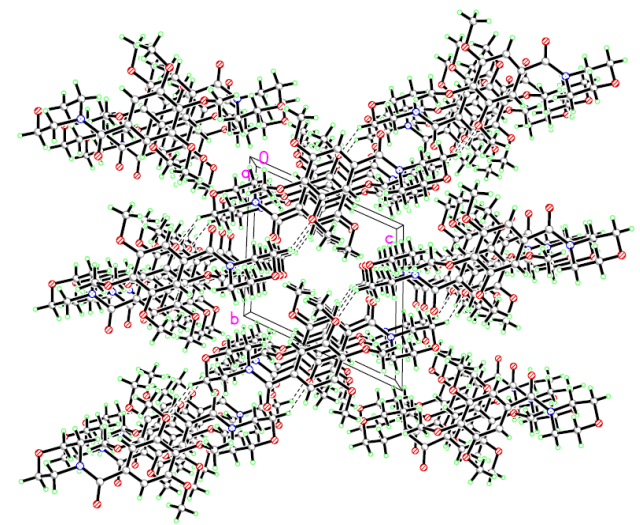

Compound e2 
Table 1. Crystal data and structure refinement for a, $\mathbf{a} 2$ and $\mathbf{e 2}$.

\begin{tabular}{|c|c|c|c|}
\hline & $\mathbf{a}$ & $\mathbf{a 2}$ & e2 \\
\hline CCDC Deposit No. & 815292 & 960811 & 960813 \\
\hline Empirical formula & $\mathrm{C}_{12} \mathrm{H}_{9} \mathrm{NO}_{6}$ & $\mathrm{C}_{12} \mathrm{H}_{13} \mathrm{NO}_{4}$ & $\mathrm{C}_{14} \mathrm{H}_{19} \mathrm{NO}_{5}$ \\
\hline Formula weight & 263.20 & 235.23 & 281.30 \\
\hline Temperature (K) & $296(2)$ & $296(2)$ & 296 \\
\hline Wavelength $(\AA)$ & 0.71073 & 0.71073 & 0.71073 \\
\hline Crystal system & Monoclinic & Orthorhombic & Triclinic \\
\hline Space group & $\mathrm{P} 2(1) / \mathrm{n}$ & $\mathrm{P}$ bca & P-1 \\
\hline $\mathrm{a}(\AA)$ & $8.7694(11)$ & $14.595(3)$ & $8.6577(9)$ \\
\hline $\mathrm{b}(\AA)$ & $6.2631(8)$ & $7.7849(14)$ & $9.5460(10)$ \\
\hline c $(\AA)$ & $22.168(3)$ & $20.112(4)$ & $9.8578(10)$ \\
\hline$\alpha\left(^{\circ}\right)$ & 90 & 90 & $64.1760(10)$ \\
\hline$\beta\left(^{\circ}\right)$ & $94.814(2)$ & 90 & $77.037(2)$ \\
\hline$\gamma\left({ }^{\circ}\right)$ & 90 & 90 & $71.6540(10)$ \\
\hline Volume $\left(\AA^{3}\right)$ & 1213.3(3) & $2285.1(7)$ & $692.44(12)$ \\
\hline Z & 4 & 8 & 2 \\
\hline$D_{\text {calc }}\left(g / \mathrm{cm}^{3}\right)$ & 1.441 & 1.368 & 1.349 \\
\hline Abs.coefficient $\left(\mathrm{mm}^{-1}\right)$ & 0.118 & 0.104 & 0.096 \\
\hline $\mathrm{F}(000)$ & 544 & 992 & 300 \\
\hline Crystal size $\left(\mathrm{mm}^{3}\right)$ & $0.14 \times 0.11 \times 0.10$ & $0.20 \times 0.10 \times 0.10$ & $0.39 \times 0.27 \times 0.20$ \\
\hline$\theta \operatorname{limit}\left({ }^{\circ}\right)$ & 1.84 to 25.10 & 2.46 to 25.00 & 2.31 to 25.00 \\
\hline Ranges/indices $h . k . l$. & $-10 / 10,-7 / 6,-26 / 26$ & $-15 / 17,-9 / 9,-23 / 17$ & $-9 / 10,-9 / 11,-11 / 11$ \\
\hline Refinement method & \multicolumn{3}{|c|}{ Full-matrix least-squares on $\mathrm{F}^{2}$} \\
\hline Reflections collected/ unique $/ \mathrm{R}_{\text {int }}$ & $5777 / 2165 / 0.043$ & $10446 / 2001 / 0.033$ & $3490 / 2432 / 0.0205$ \\
\hline Completeness to $\theta=25.10^{\circ}$ & $99.6 \%$ & $99.6 \%$ & $99.3 \%$ \\
\hline Data/restraints/parameters & $2165 / 0 / 173$ & $2001 / 0 / 155$ & $2432 / 0 / 185$ \\
\hline Goodness of fit on $\mathrm{F}^{2}$ & 1.088 & 1.023 & 1.085 \\
\hline $\mathrm{R}_{1}, \mathrm{wR} \mathrm{R}_{2}$ & $0.0456,0.1199$ & $0.0589,0.1553$ & $0.0404,0.1261$ \\
\hline Extinction coefficient & $0.020(4)$ & $0.0028(11)$ & $0.120(12)$ \\
\hline Largest diff. peak and hole (e. $\left.\AA^{-3}\right)$ & 0.149 and -0.161 & 0.489 and -0.219 & 0.155 and -0.186 \\
\hline
\end{tabular}

The crystals of 3-benzodioxole-5-carboxylic acid 2,5-dioxo-1-pyrrolidinyl ester (a) are monoclinic, space group P2(1)/n with four molecules per unit cell. The $\mathrm{O}(6)$ atom lies within the mean plane of the benzene, as indicated by $\mathrm{O}(6)-\mathrm{C}(10)-\mathrm{C}(11)-\mathrm{C}(12)$ torsion angle of $-179.16^{\circ}$. The $\mathrm{O}(5)$ atom is also in the mean plane of the benzene, as indicated by the $\mathrm{O}(6)-\mathrm{C}(10)-\mathrm{C}(11)-\mathrm{O}(5)$ torsion angle of $0.6(2)^{\circ}$. All carbon and oxygen atoms of piperonyl are in a plane. The succinimide ring also forms a plane. The dihedral angle between the mean plane of the piperonyl and succinimide rings is $74.69^{\circ}$. In the crystal packing, as shown in Figure 3, weak intermolecular hydrogen bonds are observed (showed as dashed lines).

The crystals of compound $\mathbf{a} 2$ are orthorhombic, space group Pbca with eight molecules per unit cell. The torsion angles of $\mathrm{C}(12)-\mathrm{N}(1)-\mathrm{C}(9)-\mathrm{C}(10)$ and $\mathrm{C}(11)-\mathrm{O}(4)-\mathrm{C}(10)-\mathrm{C}(9)\left[53.7(3)^{\circ}\right.$ and 58.5(3) ${ }^{\circ}$, respectively] show that the morpholine ring is in a typical chair conformation. The dihedral angle between the mean plane of benzene and a plane formed by $\mathrm{N}(1), \mathrm{C}(9)$ and $\mathrm{C}(12)$ is $89.8^{\circ}$. In the crystal 
packing, as shown in Figure 3, adjacent molecules are crossed stacked through strong offset $\pi \cdots \pi$ aromatic stacking interactions. Intermolecular hydrogen bonds are also observed.

The crystals of compound $\mathbf{e} 2$ are triclinic, space group P-1 with two molecules per unit cell. The morpholine ring is also is a typical chair conformation. In the crystal packing, as shown Figure 3 intermolecular hydrogen bonds are also observed (showed as dashed lines).

\subsection{Effect on Forced Swimming Capacity}

The forced swimming capacities are shown in Figure 4. There are significant differences in the swimming time to exhaustion between the control group and each treatment group. The swimming times to exhaustion of the caffeine (positive control group), b3, d3, and e3 groups were $1052 \pm 148 \mathrm{~s}$, $1310 \pm 85 \mathrm{~s}, 1348 \pm 139 \mathrm{~s}$, and $1378 \pm 105 \mathrm{~s}$, respectively. Thus, the swimming times to exhaustion of the b3, d3, and $\mathbf{e 3}$ groups were significantly longer than those of the caffeine group $(p<0.05)$. It is worthwhile to note that $\mathbf{b 3}, \mathbf{d} \mathbf{3}$, and $\mathbf{e} 3$ have a common pyrrolidine ring. But what is the real reason? Further observation and study are needed. On the other hand, the swimming times to exhaustion of the $\mathbf{a} 2, \mathbf{b 1}, \mathbf{b 4}, \mathbf{d 1}, \mathbf{d} 2$, and $\mathbf{e} 2$ groups were longer than that of the normal saline group. However, there was no significant difference in between the caffeine group and each of the other treatment groups.

Figure 4. Effects of compounds on the forced swimming time. ${ }^{* *} p<0.01$ compared with the saline group, $* p<0.05$ compared with the saline group, $\# p<0.05$ compared with the caffeine group.

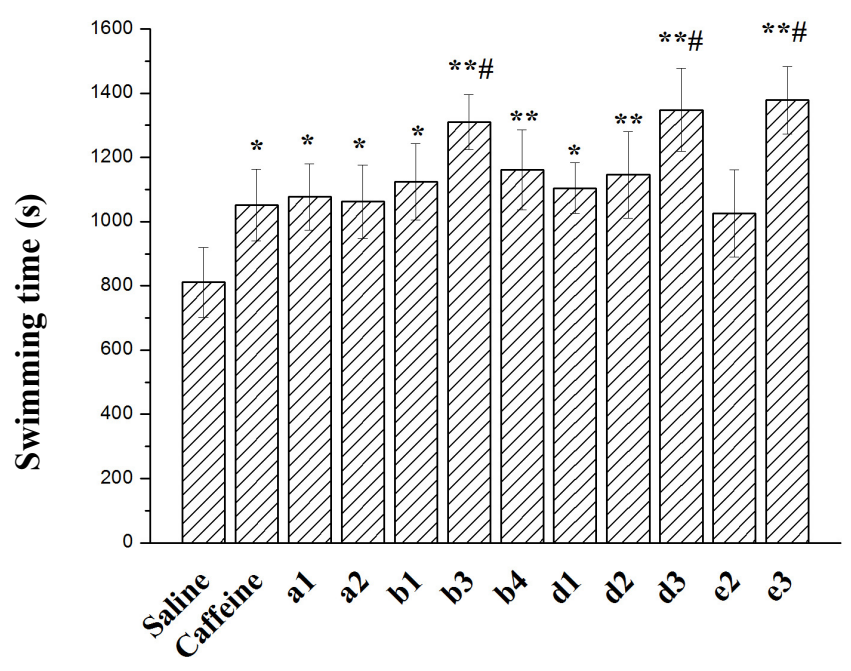

\section{Experimental}

\subsection{General Information}

Melting points were taken on a X-4 micro melting point apparatus and are uncorrected. ${ }^{1} \mathrm{H}-\mathrm{NMR}$ spectra were recorded out in $\mathrm{CDCl}_{3}$ on a Varian Inova-400 spectrometer and chemical shifts were reported relative to internal $\mathrm{Me}_{4} \mathrm{Si}$. Infrared spectra were obtained as $\mathrm{KBr}$ pellets on an Equiox-55 FTIR spectrometer. Elemental analyses were performed with a Vario EL-III instrument. The X-ray diffraction data were collected on a Bruker SMART AREX II CCD diffractometer equipped with a 
graphite monochromated Mo $K \alpha$ radiation $(\lambda=0.71073 \AA)$ source by using the $\omega-2 \theta$ scan technique at room temperature. The structure was solved by direct methods with SHELXS-97 [19], and refined using SHELXL-97 [20]. Hydrogen atoms were generated geometrically. Molecular illustrations were prepared using the XP package [21]. CCDC 815292 (for compound a), 960811 (for compound a2) and 960813 (for compound e2) contain the supplementary crystallographic data for this paper. These data can be obtained free of charge from http://www.ccdc.cam.ac.uk/conts/retrieving.html (or from the Cambridge Crystallographic Data Centre, 12, Union Road, Cambridge CB2 1EZ, UK; fax: +44 1223 336033).

\subsection{Synthesis}

\subsubsection{Preparation of $N$-Hydroxysuccinimidyl Trifluoroacetate (NHS-TFA)}

The synthesis of NHS-TFA is shown in Scheme 2. To trifluoroacetic anhydride (15 ml, $71.2 \mathrm{mmol})$, $\mathrm{N}$-hydroxysuccinimide (5 g, $42.6 \mathrm{mmol}$ ) was slowly added with vigorously stirring. On a larger scale, a condenser equipped with a drying tube may be needed. The solution was stirred at room temperature about $4 \mathrm{~h}$ until the reaction was completed. The reaction solution was evaporated in vacuo to remove trifluoroacetic anhydride and trifluoroacetic acid to give a thick oil. Then, it was further dried below $70{ }^{\circ} \mathrm{C}$ until a free-flowing colorless solid was obtained. The product is of good quality if it gives bubbles when dissolved in methanol.

Scheme 2. Preparation of N-hydroxysuccinimidyl trifluoroacetate.
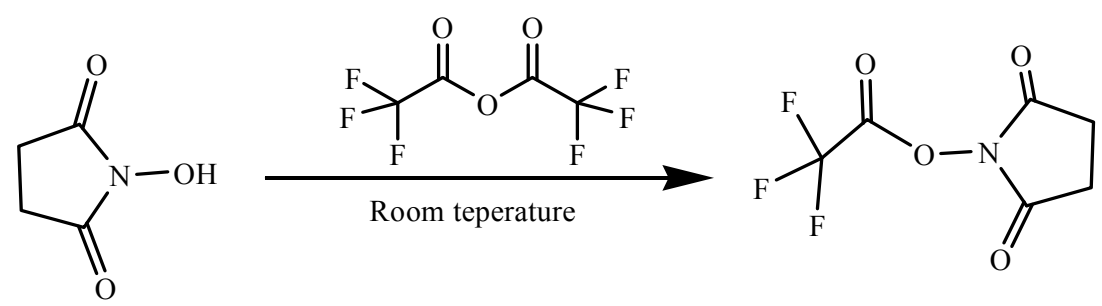

\subsubsection{Synthesis of 3-Benzodioxole-5-carboxylic acid, 2,5-dioxo-1-pyrrolidinyl Ester (a)}

Piperic acid (1.66 g, $10 \mathrm{mmol})$ was dissolved in anhydrous THF $(50 \mathrm{~mL})$ followed by the addition of anhydrous pyridine $(4 \mathrm{~mL})$ and N-hydroxysuccinimidyl trifluoroacetate (NHS-TFA) (6.33 g, $30 \mathrm{mmol}$ ). The reaction mixture was stirred at room temperature for $4 \mathrm{~h}$. The reaction mixture was concentrated under reduced pressure. The residue was dissolved in $\mathrm{CH}_{2} \mathrm{Cl}_{2}(80 \mathrm{~mL})$ and washed with $1 \mathrm{~mol} / \mathrm{L} \mathrm{HCl}$ (3 $\times 80 \mathrm{~mL})$, followed by saturated brine $(3 \times 80 \mathrm{~mL})$. The organic layer was dried over anhydrous $\mathrm{Na}_{2} \mathrm{SO}_{4}$, filtered and concentrated to give 3-benzodioxole-5-carboxylic acid, 2,5-dioxo-1-pyrrolidinyl ester (a). Single crystals of (a) for X-ray diffraction experiments were grown from ethanol-water mixture (1:1). White solid; Yield: 88\%; m.p. $152-154{ }^{\circ} \mathrm{C}$; FTIR $\left(\mathrm{cm}^{-1}\right)$ : 3103, 2995, 2913, 1771, 1730, 1623, 1485, 1442, 1375, 1263, 1210, 1073, 994, 830; ${ }^{1} \mathrm{H}-\mathrm{NMR}\left(\mathrm{CDCl}_{3}\right) \delta: 2.91(\mathrm{~s}, 4 \mathrm{H}), 6.09$ (s, 2H), $6.90(\mathrm{~d}, 1 \mathrm{H}), 7.51(\mathrm{~s}, 1 \mathrm{H}), 7.76(\mathrm{~d}, 1 \mathrm{H})$; Anal. calcd. For $\mathrm{C}_{12} \mathrm{H}_{9} \mathrm{NO}_{6}: \mathrm{C}, 54.76 ; \mathrm{H}, 3.45 ; \mathrm{N}, 5.32$; Found C, 54.72; H, 3.41; N, 5.27. 


\subsubsection{Synthesis of 3,4-Dimethoxybenzoic acid, 2,5-dioxo-1-pyrrolidinyl ester (b)}

Compound $\mathbf{b}$ was prepared from 3,4-dimethoxybenzoic acid (1.82 g, $10 \mathrm{mmol})$ and NHS-TFA (6.33 g, $30 \mathrm{mmol}$ ) by the procedure utilized for compound $\mathbf{a}$. Compound $\mathbf{b}$ was obtained as a white solid in 84\% yield. FTIR $\left(\mathrm{cm}^{-1}\right): 3094,3023,2940,2841,1734,1599,1513,1458,1448,1417,1373,1273$, 1206, 1143, 1071, 1017, 878, 810; ${ }^{1} \mathrm{H}-\mathrm{NMR}\left(\mathrm{CDCl}_{3}\right) \delta: 2.92$ (s, 4H), 3.94 (s, 6H), 6.94 (d, 1H, J= 8.8 Hz), $7.57(\mathrm{~s}, 1 \mathrm{H}), 7.82(\mathrm{~d}, 1 \mathrm{H}, J=6.8 \mathrm{~Hz})$; Anal. calcd. For $\mathrm{C}_{13} \mathrm{H}_{13} \mathrm{NO}_{6}: \mathrm{C}, 55.91$; $\mathrm{H}, 4.69$; N, 5.02; Found C, 55.89; H, 4.67; N, 5.04 .

\subsubsection{Synthesis of 4-Methoxybenzoic acid, 2,5-dioxo-1-pyrrolidinyl ester (d)}

This compound was prepared from 4-methoxybenzoic acid (1.52 g, $10 \mathrm{mmol})$ and NHS-TFA (6.33 g, $30 \mathrm{mmol}$ ) by the procedure utilized for compound a. Compound (d) was obtained as a white solid in 86\% yield. m.p. $142-144{ }^{\circ} \mathrm{C}$; FTIR $\left(\mathrm{cm}^{-1}\right)$ : 3433, 3111, 2940, 2848, 1766, 1735, 1602, 1514, 1457 , 1427, 1377, 1271, 1255, 1216, 1183, 1073, 1022, 984, 847, 757; ${ }^{1} \mathrm{H}-\mathrm{NMR}\left(\mathrm{CDCl}_{3}\right) \delta: 2.89$ (s, 4H), $3.89(\mathrm{~s}, 3 \mathrm{H}), 6.97(\mathrm{~d}, 2 \mathrm{H}, J=8.8 \mathrm{~Hz}), 8.09(\mathrm{~d}, 2 \mathrm{H}, J=8.8 \mathrm{~Hz})$.

\subsubsection{Synthesis of 3,4,5-Trimethoxybenzoic acid, 2,5-dioxo-1-pyrrolidinyl Ester (e)}

This compound was prepared from 3,4,5-trimethoxybenzoic acid (2.12 g, $10 \mathrm{mmol})$ and NHS-TFA $(6.33 \mathrm{~g}, 30 \mathrm{mmol})$ by the procedure utilized for compound a. Compound (e) was obtained as white solid in 80\% yield. m.p. $125-127{ }^{\circ} \mathrm{C}$; FTIR $\left(\mathrm{cm}^{-1}\right)$ : 2997, 2952, 1763, 1734, 1588, 1504, 1469, 1422, 1339, 1260, 1241, 1203, 1166, 1128, 1078, 989, 892, 750; ${ }^{1} \mathrm{H}-\mathrm{NMR}\left(\mathrm{CDCl}_{3}\right) \delta: 2.91(\mathrm{~s}, 4 \mathrm{H}), 3.92(\mathrm{~s}$, 9H), 7.38(s, 2H).

\subsubsection{Synthesis of Compounds $\mathbf{a} 1$ and $\mathbf{a} 2$}

3-Benzodioxole-5-carboxylic acid, 2,5-dioxo-1-pyrrolidinyl ester (2.63 g, $10 \mathrm{mmol})$ was dissolved in $\mathrm{CH}_{2} \mathrm{Cl}_{2}(50 \mathrm{~mL})$ followed by the addition of piperidine $(2 \mathrm{~mL})$. The resultant mixture was stirred at room temperature for $2 \mathrm{~h}$. The mixture was washed with $1 \mathrm{~mol} / \mathrm{L} \mathrm{HCl}(3 \times 80 \mathrm{~mL})$ and saturated brine $(3 \times 80 \mathrm{~mL})$, and then dried over anhydrous $\mathrm{Na}_{2} \mathrm{SO}_{4}$. The solvent was removed under reduced pressure and the residue was crystallized from ethanol as needles. The compound a1 was obtained as a white powder. Compound a2 were prepared according to the same procedure. Single crystals of compound (a2) for X-ray diffraction experiments were grown from ethanol.

$\mathrm{N}$-(3,4-methylenedioxybenzoyl) piperidine (a1). Needle-like solid; Yield: 83\%; m.p. 51-52 ${ }^{\circ} \mathrm{C}$ (lit. [22]: 51-52 ${ }^{\circ} \mathrm{C}$ ); FTIR $\left(\mathrm{cm}^{-1}\right)$ : 3071, 3006, 2926, 2853, 1713, 1607, 1445, 1282, 1248, 1077, 1034, 929, 802; ${ }^{1} \mathrm{H}-\mathrm{NMR}\left(\mathrm{CDCl}_{3}\right) \delta: 1.56-1.67(\mathrm{~m}, 6 \mathrm{H}), 3.43(\mathrm{t}, 4 \mathrm{H}), 6.00(\mathrm{~s}, 2 \mathrm{H}), 6.80(\mathrm{~d}, 1 \mathrm{H})$, $6.89(\mathrm{~s}, 1 \mathrm{H}), 6.92(\mathrm{~d}, 1 \mathrm{H})$. Anal. calcd. For $\mathrm{C}_{13} \mathrm{H}_{15} \mathrm{NO}_{3}$ : C, 66.97; H, 6.52; N, 5.97; Found C, 66.94; H, $6.48 ; \mathrm{N}, 6.00$.

$N$-(3,4-methylenedioxybenzoyl) morpholine (a2). Needle-like solid; Yield: 80\%; m.p. 82-84 ${ }^{\circ} \mathrm{C}$ (lit. [23]: 83-84 ${ }^{\circ} \mathrm{C}$ ); FTIR ( $\left.\mathrm{cm}^{-1}\right)$ : 3433, 3040, 2974, 2899, 2859, 1620, 1494, 1444, 1368, 1342, 1283, 1246, 1108, 1037,940, 833; ${ }^{1} \mathrm{H}-\mathrm{NMR}\left(\mathrm{CDCl}_{3}\right) \delta: 3.69(\mathrm{~s}, 8 \mathrm{H}), 6.00(\mathrm{~s}, 2 \mathrm{H}), 6.83(\mathrm{~d}, 1 \mathrm{H}, J=8.0 \mathrm{~Hz})$, 
$6.91(\mathrm{~s}, 1 \mathrm{H}), 6.93(\mathrm{~d}, 1 \mathrm{H}, J=8 \mathrm{~Hz})$; Anal. calcd. For $\mathrm{C}_{12} \mathrm{H}_{13} \mathrm{NO}_{4}: \mathrm{C}, 61.27$; $\mathrm{H}, 5.57$;, 5.95; Found C, $61.59 ; \mathrm{H}, 5.52 ; \mathrm{N}, 5.98$.

\subsubsection{Synthesis of Compounds b1, b3 and b4}

These compounds were prepared from 3,4-dimethoxybenzoic acid, 2,5-dioxo-1-pyrrolidinyl ester and piperidine (pyrrolidine or 4-methylpyridine) by the procedure utilized for compound $\mathbf{a} 1$.

$N-\left(3,4-\right.$ Dimethoxybenzoyl) piperidine (b1). White solid; Yield: $84 \%$; m.p. $35-36{ }^{\circ} \mathrm{C}$ (lit. [24]: $\left.35-37{ }^{\circ} \mathrm{C}\right)$; FTIR $\left(\mathrm{cm}^{-1}\right)$ : 3443, 2943, 2855, 1617, 1580, 1518, 1432, 1331, 1267, 1137, 1018, 870; ${ }^{1} \mathrm{H}-\mathrm{NMR}$ $\left(\mathrm{CDCl}_{3}\right) \delta: 1.55-1.68(\mathrm{~m}, 6 \mathrm{H}), 3.45-3.65(\mathrm{~m}, 4 \mathrm{H}), 3.86(\mathrm{~s}, 6 \mathrm{H}), 6.86(\mathrm{~d}, 1 \mathrm{H}, J=8.0 \mathrm{~Hz}), 6.97(\mathrm{~d}, 1 \mathrm{H}$, $J=8.0 \mathrm{~Hz}), 6.98(\mathrm{~s}, 1 \mathrm{H})$.

N-(3,4-Dimethoxybenzoyl) pyrrolidine (b3). Colorless oil; Yield: 83\%; FTIR ( $\left.\mathrm{cm}^{-1}\right)$ : 3437, 2972, 2935, 2875, 1612, 1575, 1512, 1454, 1417, 1384, 1328, 1249, 1176, 1120, 1022, 869, 821, 758; ${ }^{1} \mathrm{H}-\mathrm{NMR}\left(\mathrm{CDCl}_{3}\right) \delta: 1.87(\mathrm{t}, 2 \mathrm{H}, J=6.4 \mathrm{~Hz}), 1.96(\mathrm{t}, 2 \mathrm{H}, J=6.4 \mathrm{~Hz}), 3.50(\mathrm{t}, 2 \mathrm{H}, J=6.0 \mathrm{~Hz}), 3.64(\mathrm{t}$, $2 \mathrm{H}, J=6.4 \mathrm{~Hz}), 3.91(\mathrm{~s}, 6 \mathrm{H}), 6.85(\mathrm{~d}, 1 \mathrm{H}, J=8.0 \mathrm{~Hz}), 7.12(\mathrm{~d}, 1 \mathrm{H}, J=8.8 \mathrm{~Hz}), 7.14(\mathrm{~s}, 1 \mathrm{H})$.

(3,4-Dimethoxyphenyl)(4-methyl-1-piperidinyl) methanone (b4). Colorless oil; Yield: 82\%; FTIR $\left(\mathrm{cm}^{-1}\right): 3444,2957,2863,1631,1517,1437,1324,1271,1141,1072,818 ;{ }^{1} \mathrm{H}-\mathrm{NMR}\left(\mathrm{CDCl}_{3}\right) \delta: 0.98$ $(\mathrm{d}, 3 \mathrm{H}, J=5.6 \mathrm{~Hz}), 1.15-1.24(\mathrm{~m}, 2 \mathrm{H}), 1.61-1.79(\mathrm{~m}, 4 \mathrm{H}), 3.90(\mathrm{~s}, 6 \mathrm{H}),, 6.85(\mathrm{~d}, 1 \mathrm{H}, J=8.0 \mathrm{~Hz}), 6.97$ (d, $1 \mathrm{H}, J=8.4 \mathrm{~Hz}), 6.98(\mathrm{~s}, 1 \mathrm{H})$.

\subsubsection{Synthesis of Compound $\mathbf{d} \mathbf{1}-\mathbf{d} \mathbf{3}$}

These compounds were prepared from 4-methoxybenzoic acid, 2,5-dioxo-1-pyrrolidinyl ester and piperidine (morpholine or pyrrolidine) by the procedure utilized for compound $\mathbf{a} 1$.

N-(4-Methoxybenzoyl) piperidine (d1). Colorless oil; Yield: 80\%; ${ }^{1} \mathrm{H}-\mathrm{NMR}\left(\mathrm{CDCl}_{3}\right) \delta$ : $1.58-1.67$ (m, $6 \mathrm{H}), 3.30-3.71(\mathrm{~m}, 4 \mathrm{H}), 3.83(\mathrm{~s}, 3 \mathrm{H}), 6.90(\mathrm{~d}, 2 \mathrm{H}, J=8.4 \mathrm{~Hz}), 7.37$ (d, 2H, $J=8.4 \mathrm{~Hz})$. The properties match those reported in the literature [25].

N-(4-Methoxybenzoyl) morpholine (d2). Colorless oil. Yield: 82\%; FTIR ( $\left.\mathrm{cm}^{-1}\right)$ : 3427, 3188, 2931, 2859, 1764, 1690, 1645, 1610, 1494, 1459, 1321, 1254, 1229, 1168, 1109, 1051, 1028, 838, 757, 706;

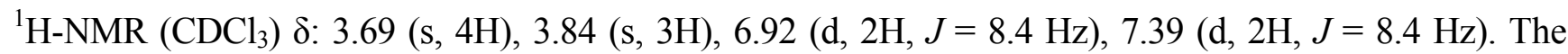
properties match those reported in the literature [13].

N-(4-Methoxybenzoyl) pyrrolidine (d3). White solid; Yield: 85\%; m.p. 76-77 ${ }^{\circ} \mathrm{C}$ (lit. [26]: 78.4-78. ${ }^{\circ} \mathrm{C}$ ); FTIR $\left(\mathrm{cm}^{-1}\right)$ : 3521, 3111, 3082, 2847, 1766, 1735, 1602, 1514, 1457, 1427, 1377, $1271,1255,1217,1183,1074,1022,984,847,757 ;{ }^{1} \mathrm{H}-\mathrm{NMR}\left(\mathrm{CDCl}_{3}\right) \delta: 1.85-1.90(\mathrm{~m}, 2 \mathrm{H}), 1.92-1.97$ $(\mathrm{m}, 2 \mathrm{H}), 3.48(\mathrm{t}, 2 \mathrm{H}, J=6.4 \mathrm{~Hz}), 3.65(\mathrm{t}, 2 \mathrm{H}, J=6.8 \mathrm{~Hz}), 3.84(\mathrm{~s}, 3 \mathrm{H}), 6.90(\mathrm{~d}, 2 \mathrm{H}, J=8.8 \mathrm{~Hz}), 7.52$ $(\mathrm{d}, 2 \mathrm{H}, J=8.8 \mathrm{~Hz})$. 


\subsubsection{Synthesis of Compounds $\mathbf{e} 2$ and $\mathbf{e} 3$}

Compounds $\mathbf{e} 2$ and $\mathbf{e} 3$ were prepared from 3,4,5-trimethoxybenzoic acid, 2,5-dioxo-1-pyrrolidinyl ester and morpholine or pyrrolidine by the procedure utilized for compound a1. Single crystals of compound $\mathbf{e} 2$ for X-ray diffraction experiments were grown from ethanol.

N-(3,4,5-Trihydroxybenzoyl) morpholine (e2). White solid; Yield: 79\%; m.p. 97-99 ${ }^{\circ} \mathrm{C}$ (lit. [12]: 96-98 $\left.{ }^{\circ} \mathrm{C}\right)$; FTIR $\left(\mathrm{cm}^{-1}\right): 3430,2974,2934,2871,1765,1637,1586,1449,1416,1327,1233,1132$, 958, 854; ${ }^{1} \mathrm{H}-\mathrm{NMR}\left(\mathrm{CDCl}_{3}\right)$ $\delta: 3.69-3.71(\mathrm{~m}, 4 \mathrm{H}), 3.87$ (s, 9H), $6.63(\mathrm{~s}, 2 \mathrm{H})$.

N-(3,4,5-Trihydroxybenzoyl) pyrrolidine (e3). White solid; Yield: $84 \%$; m.p. $182-183{ }^{\circ} \mathrm{C}$. (lit. [27]: 183-186 ${ }^{\circ} \mathrm{C}$ ); ${ }^{1} \mathrm{H}-\mathrm{NMR}\left(\mathrm{CDCl}_{3}\right) \delta: 1.89$ (dd, $\left.2 \mathrm{H}, J=7.4 \mathrm{~Hz}, 6.0 \mathrm{~Hz}\right), 1.97$ (dd, 2H, $J=6.8 \mathrm{~Hz}, 6.4 \mathrm{~Hz}$ ), $3.46(\mathrm{t}, 2 \mathrm{H}, J=6.8 \mathrm{~Hz}), 3.64(\mathrm{t}, 2 \mathrm{H}, J=6.8 \mathrm{~Hz}), 3.86(\mathrm{~s}, 9 \mathrm{H}), 6.75(\mathrm{~s}, 2 \mathrm{H})$.

\subsection{Anti-Fatigue Activity Assessment of Benzamide Derivatives}

\subsubsection{Animals}

Six-week-old male Kunming mice (18-22 g, specific pathogen-free grade, SPF) were obtained from the Academy of Experimental Animal Center of The Fourth Military Medical University (Xi'an, China). Mice were maintained under normal conditions: $21-26{ }^{\circ} \mathrm{C}$ temperature, $60 \%-70 \%$ relative humidity, 12:12 h dark/light cycle, and free access to laboratory standard diet and water. All mice were quarantined and adapted for 7 days after arriving. All animal experiments were conducted under institutional guidelines and approved by the Ethical Committee for Animal Care and Use of the Fourth Military Medical University.

\subsubsection{Anti-Fatigue Activity}

The anti-fatigue activity of benzamide derivatives was evaluated by the weight loaded swimming model in mice. The model is a reliable measure of anti-fatigue treatment as established in both laboratory animals and humans [28-30]. All mice were randomly divided into 12 groups, two control groups and ten treatment groups, seven mice per group. Benzamide derivatives were dissolved in carboxymethylcellulose sodium (CMC) $5 \mathrm{~g} / \mathrm{L}$ aqueous solution, respectively. One control group received the same volume of saline solution. Another control group received caffeine as a positive control group. Benzamide derivatives were given to mice at concentrations of $0.1 \mathrm{mmol} / \mathrm{kg}$ body weight. Samples were orally administered into mice using a feeding atraumatic needle, once per day at 1:00-3:00 pm for one week. After each treatment, all groups of the mice were allowed to rest $30 \mathrm{~min}$ and were forced to swim for ten minutes to become accustomed to swimming. The size of swimming pool was designed as $50 \mathrm{~cm} \times 50 \mathrm{~cm} \times 40 \mathrm{~cm}$, filled with fresh water at $30 \pm 2{ }^{\circ} \mathrm{C}$. A tin wire $(5 \%$ of body weight) was loaded on the tail root of the mouse. The mice were assessed to be exhausted when they failed to rise to the surface of water to breathe within a $7 \mathrm{~s}$ period [31]. At the end of the session, the mice were removed from the water, dried with a paper towel, and placed back in their home cages. Water in the container was drained after each session. The swimming time to exhaustion was used as the index of the forced swimming capacity. 


\subsubsection{Statistical Analysis}

Data were analyzed using SPSS 13.0 version. The results were expressed as the mean \pm S.E.M. The data were subjected to one-way analysis of variance (ANOVA) followed by Tukey-Kramer post-hoc analysis. The level of $p<0.05$ was used as the criterion of statistical significance.

\section{Conclusions}

In the current study, we have established for the first time a rapid and highly efficient method for the synthesis of benzamide derivatives. The structures of the compounds have been determined by FTIR and ${ }^{1}$ H-NMR spectroscopy, elemental analysis and X-ray diffraction of select examples (compounds $\mathbf{a}, \mathbf{a} 2$ and $\mathbf{e 2}$ ). The crystal structures have potential applications in identifying the binding site for allosteric modulators of the AMPA receptor, and should be useful in the area of medical or pharmaceutical applications.

Preliminary studies suggest that compound b3, $\mathbf{d 3}$ and $\mathbf{e} \mathbf{3}$ increased swimming time to exhaustion in weight-loaded forced swimming mice. They have potential application in developing new drug candidates with anti-fatigue activity. Because a large number of complex mechanisms may be involved in the exercise-induced fatigue, further research including molecular study is required to evaluate the anti-fatigue mechanism.

\section{Acknowledgments}

The project was supported by the National Natural Science Foundation of China (No. 21202130, 81073037, and 81202457), the National Special Foundation of State Center for Drug Research and Development (No. 2008ZXJ09004-024, 2009ZXG09001-020). Guo-ping Yang and Xiang-han Zhang are thanked for their warm support.

\section{Conflicts of Interest}

The authors declare no conflict of interest.

\section{References}

1. Black, M.D. Psychopharmacology of glutamate-therapeutic potential of positive AMPA modulators. Psychopharmacology 2005, 179, 154-163.

2. Lomeli, H.; Mosbacher, J.; Melcher, T.; Hoger, T.; Kuner, T.; Monyer, H.; Higuchi, M.; Bach, A.; Seeburg, P.H. Control of kinetic properties of AMPA receptor channels by nuclear RNA editing. Science 1994, 266, 1709-1713.

3. Sommer, B.; Keinanen, K.; Verdoorn, T.A.; Wisden, W.; Burnashev, N.; Herb, A.; Kohler, M.; Takagi, T.; Sakmann, B.; Seeburg, P.H. Flip and flop: A cell-specific functional switch in glutamate-operated channels of the CNS. Science 1990, 249, 1580-1585.

4. Arai, A.; Kessler, M.; Xiao, P.; Ambros-Ingerson, J.; Rogers, G.; Lynch, G. A centrally active drug that modulates AMPA receptor gated currents. Brain Res. 1994, 638, 343-346. 
5. Yamada, K.A. AMPA receptor activation potentiated by the AMPA modulator 1-BCP is toxic to cultured rat hippocampal neurons. Neurosci. Lett. 1998, 249, 119-122.

6. Ito, I.; Tanabe, S.; Kohda, A.; Sugiyama, H. Allosteric potentiation of quisqualate receptors by nootropic drug aniracetam. J. Physiol. 1990, 424, 533-543.

7. Kessler, M.; Arai, A.C. Use of $\left[{ }^{3} \mathrm{H}\right]$ fluorowillardiine to study properties of AMPA receptor allosteric modulators. Brain Res. 2006, 1076, 25-41.

8. Jordan, G.R.; McCulloch, J.; Shahid, M.; Hill, D.R.; Henry, B.; Horsburgh, K. Regionally selective and dose-dependent effects of the ampakines Org 26576 and Org 24448 on local cerebral glucose utilisation in the mouse as assessed by ${ }^{14} \mathrm{C}-2$-deoxyglucose autoradiography. Neuropharmacology 2005, 49, 254-264.

9. Johnson, S.A.; Luu, N.T.; Herbst, T.A.; Knapp, R.; Lutz, D.; Arai, A.; Lynch, G. Synergistic interactions between ampakines and antipsychotic drugs. J. Pharmacol. Exp. Ther. 1999, 289, 392-397.

10. Bahr, B.A.; Bendiske, J.; Brown, Q.B.; Munirathinam, S.; Caba, E.; Rudin, M.; Urwyler, S.; Sauter, A.; Rogers, G. Survival signaling and selective neuroprotection through glutamatergic transmission. Exp. Neurol. 2002, 174, 37-47.

11. Lauterborn, J.C.; Truong, G.S.; Baudry, M.; Bi, X.; Lynch, G.; Gall, C.M. Chronic elevation of brain-derived neurotrophic factor by ampakines. J. Pharmacol. Exp. Ther. 2003, 307, 297-305.

12. Yang, X.D.; Zeng, X.H.; Zhao, Y.H.; Wang, X.Q.; Pan, Z.Q.; Li, L.; Zhang, H.B. Silica gel-mediated amide bond formation: An environmentally benign method for liquid-phase synthesis and cytotoxic activities of amides. J. Comb. Chem. 2010, 12, 307-310.

13. Kawagoe, Y.; Moriyama, K.; Togo, H. Facile preparation of amides from carboxylic acids and amines with ion-supported $\mathrm{Ph}_{3} \mathrm{P}$. Tetrahedron 2013, 69, 3971-3977.

14. Do, G.S.; Lim, J.K.; Woo, W.S. Synthesis and central nervous depressant activities of piperdine derivatives. Yakhak. Hoechi. 1986, 30, 163-168.

15. Naota, T.; Murahashi, S.-I. Ruthenium-catalyzed transformations of amino alcohols to lactams. Synlett 1991, 10, 693-694.

16. Wu, X.F.; Neumann, H.; Beller, M. Selective palladium-catalyzed aminocarbonylation of aryl halides with CO and ammonia to primary amides. Chem. Eur. J. 2010, 16, 9750-9753.

17. Troisi, L.; Granito, C.; Rosato, F.; Videtta, V. One-pot amide synthesis from allyl or benzyl halides and amines by Pd-catalysed carbonylation. Tetrahedron Lett. 2010, 51, 371-373.

18. Wu, X.L.; Fan, W.T.; Kong, X.H.; Wang, J.; Liu, L.; Mei, Q.B. Process for the preparation of benzodioxolecarboxamide and benzodioxancarboxamide derivatives. CN 102276576 A 20111214, China, 2011.

19. Sheldrick, G.M. SHELXS-97, Program for Solution Crystal Structure; University of Göttingen: Göttingen, Germany, 1997.

20. Sheldrick, G.M. SHELXL-97, Program for Solution Crystal Structure and Refinement; University of Göttingen: Göttingen, Germany, 1997.

21. Stereochemical Workstation Operation Manual, Release 3.4; Siemens Analytical X-ray Instruments Inc.: Madison, WI, USA, 1989. 
22. Lavrov, M.I.; Lapteva, V.L.; Grigor'ev, V.V.; Palyulin, V.A.; Bachurin, S.O.; Zefirov, N.S. Synthesis and AMPA-receptor modulating activity of benzodioxanecarboxylic and piperonylic acid derivatives. Pharm. Chem. J. 2012, 46, 92-95.

23. Greenhouse, R.; Ramirez, C.; Muchowski, J.M. Synthesis of alkylpyrroles by the sodium borohydride reduction of acylpyrroles. J. Org. Chem. 1985, 50, 2961-2965.

24. Narasimhan, B.; Ohlan, S.; Ohlan, R.; Judge, V.; Narang, R. Hansch analysis of veratric acid derivatives as antimicrobial agents. Eur. J. Med. Chem. 2009, 44, 689-700.

25. Zhang, J.; Wei, Y.; Lin, S.; Liang, F.; Liu, P. Copper-catalyzed aerobic oxidative synthesis of $\alpha$-ketoamides from methyl ketones, amines and NIS at room temperature. Org. Biomol. Chem. 2012, 10, 9237-9242.

26. Li, J.; Xu, F.; Zhang, Y.; Shen, Q. Heterobimetallic lanthanide/sodium phenoxides: Efficient catalysts for amidation of aldehydes with amines. J. Org. Chem. 2009, 74, 2575-2577.

27. Vargha, L.; Kasztreiner, E.; Borsy, J.; Farkas, L.; Kuszmann, J.; Dumbovich, B. Synthesis and pharmacological investigation of new alkoxybenzamides-I: 3, 4, 5-Trimethoxybenzamides. Biochem. Pharmacol. 1962, 11, 639-649.

28. Jung, K.A.; Han, D.; Kwon, E.K.; Lee, C.H.; Kim, Y.E. Antifatigue effect of rubus coreanus miquel extract in mice. J. Med. Food 2007, 10, 689-693.

29. Jia, J.M.; Wu, C.F. Antifatigue activity of tissue culture extracts of saussurea involucrata. Pharm. Biol. 2008, 46, 433-436.

30. Selsby, J.T.; Beckett, K.D.; Kern, M. Swim performance following creatine supplementation in division III athletes. J. Strength Cond. Res. 2003, 17, 421-424.

31. Jung, K.; Kim, I.H.; Han, D. Effect of medicinal plant extracts on forced swimming capacity in mice. J. Ethnopharmacol. 2004, 93, 75-81.

Sample Availability: Samples of the compounds are available from the authors.

(C) 2014 by the authors; licensee MDPI, Basel, Switzerland. This article is an open access article distributed under the terms and conditions of the Creative Commons Attribution license (http://creativecommons.org/licenses/by/3.0/). 